\section{Paweł Podeszwa}

Adam Mickiewicz University in Poznań

podpaw@amu.edu.pl

ORCID: 0000-0002-4000-1660

DOI: http://dx.doi.org/10.12775/BPTh.2019.004

\section{Biblica}

et

Patristica

Thoruniensia

12 (2019) 1: 93-99

ISSN (print) 1689-5150

ISSN (online) 2450-7059

\title{
Book Review: M. Moj, Kompozycje warstwowe w Ewangelii Marka, (Sandwich Technique in the Gospel of Mark) Attende Lectioni. Series Nova no 1, Tarnów 2018, 367 p., ISBN: 978-83-7793-607-8
}

Keywords: New Testament; Gospel According to St. Mark; sandwich structures; identity of Jesus.

Słowa kluczowe: Nowy Testament; Ewangelia według św. Marka; struktury kanapkowe; tożsamość Jezusa.

$\mathrm{T}$ The oldest and at the same time the shortest of synoptic gospels, the Gospel according to St. Mark, has been the subject of numerous research studies, especially since the second half of the $19^{\text {th }}$ century. The interest in the Markan text has increased with the acceptance of the two-source hypothesis by many biblical scholars which implies the primacy of chronologically second canonical gospel and the use of this text by Mathew and Luke. Scholars researching the Gospel of Mark frequently emphasize that one of its fundamental literary and theological motifs is the question about the identity of Jesus. Both His disciples and the readers/listeners of the Gospel are to find the answer to the question who Jesus is. St. Mark himself answers it through the content of the book but also through redaction techniques applied. This gives his work a kerygmatic character and the Gospel of Mark is sometimes called the "Gospel of catechumens".

The study which addresses the literary and theological craftsmanship of St. Mark is the book of Father Marcin Moj Kompozycje warstwowe w Ewangelii Marka (Sandwich Technique in the Gospel of Mark) edited by Father Artur Malina and published as the first volume of the new series Attende Lectioni. Series Nova by the Faculty of Theology of the University of Silesia in Katowice.

In the text of the Gospel there are some pericopes which can be graphically described by the following scheme A - B - A', which shows that pericope (A)

1 C.M. Martini, Stuchać Jezusa, p. 6. 
is interrupted by other event (B) and subsequently there is the return to the interrupted narration (A)'. Such a literary technique is called intercalation ${ }^{2}$ or a sandwich technique (sandwiching) and constitutes the subject of the research. The author does not only focus on establishing the number of these structures in the Gospel, which is not an easy task in itself, taking into consideration the multiplicity of opinions expressed by scholars but also poses an interesting question about the significance of using these literary structures by Mark.

In order to answer the research question, which is formulated in a clear and precise manner, the author suggests a study consisting of three logically connected parts. The first one presents the current state of research on sandwich technique in the Gospel of Mark and the problem of criteria applied to distinguish such sandwich pericopes in the text. The second part is a comprehensive study of eight pericopes which are considered to be sandwich structures. The six pericopes which are commonly acknowledged as such are discussed first and later the two remaining ones which possess "almost all features of sandwich structure among questionable (uncertain) pericopes" (p.16). These pericopes have been analyzed in a canonical order. The third part of the study is devoted to the assessment of the usefulness and precision of individual criteria applied to distinguish sandwich structures in the Gospel in order to discuss characteristic features of combined narratives and their role in the theology of the Gospel of Mark.

The book under review starts with the table of contents (pp. 5-11), list of abbreviations (p.13) and introduction (pp. 15-17), in which the author explains the reason why he decided to undertake this theme and clearly and precisely describes the research problem. It focuses on such questions as the significance of using sandwich technique by Mark, the study of criteria defining such compositions, a detailed analysis of the pericopes in which the sandwich technique is applied that finally leads to the discovery of the significance and function of this literary technique in the Markan Gospel. After discussing the research problem the author presents the structure of his work indicating briefly the content of each chapter of the book. The introduction has been written in a clear and logical manner and includes all necessary elements, such as the justification of the chosen theme, the description of the research subject, the explanation of the adopted research method (it is a shame that it has not been named) and a concise but sufficient presentation of the structure of the book and the content of each chapter.

2 The English term is sometimes translated into Polish, for example M. Rosik, Chrystologiczna funkcja interkalacji, pp. 111-137. The author of the book under review mentions this terminological problem in Polish biblical literature, see p. 46, especially footnote 167. 
The first part of the study entitled "Sandwich Compositions in Markan Exegesis" (it would be better to specify in the title that it refers to the Gospel of Mark) consists of two chapters. Firstly, the author discusses in detail the current state of research on sandwich technique in the Markan Gospel. Father Moj, quite rightly, starts with the presentation of two monographs (by Wright and Shepherd) and the chapter from the book by Deppe which is devoted to the theological aims of sandwich compositions. In the second subparagraph he discusses in the chronological order the most important papers on this theme (by Edwards, van Oyen, Downing, Rosik and Kusio). The presentation of the status quaestionis unambiguously testifies to the complexity of the problem, the diversity of the criteria for distinguishing pericopes characterized by sandwich composition, which, in turn, leads to a changing number of Markan fragments considered to be sandwich compositions by individual authors. Fr. Moj also indicates the variety of terminology used. The presentation of the state of research is very clear and has been documented with appropriate bibliographical references. In the second paragraph of the first chapter, Fr. Moj briefly shows the importance of research to date, its chronological development, emphasizing that "nowadays, in biblical exegesis, the primacy of synchronic analysis is visible, which is based on a very detailed and precise understanding of all connections between particular elements of narration" (p. 48). The wealth of collected material justifies the choice made by the author to discuss the status quaestionis in the first chapter, not in the introduction to the monograph. Undoubtedly, we have to agree with the author that "such an extensive study on sandwich technique has not been published yet in both the Polish and the international biblical studies" (p. 13). A careful reading of the status quaestionis also confirms that the subject matter chosen by the author of the book not only fits perfectly into the most current studies of the Markan Gospel, but, above all, provides a reliable study of the suitability of individual criteria for distinguishing sandwich pericopes indicating the most objective ones which allow us to recognize pericopes with such a structure. A detailed exegetical analysis of these compositions is necessary and valuable, as it answers the question about their significance and functions in Markan narrative and theology.

The second chapter of the first part is devoted to the conditions of distinguishing sandwich compositions in Markan narrative. As many authors consider irony as an important element of Markan narrative and the main rhetorical device (e.g. Faegin), the author rightly starts with the presentation of this problem in the first paragraph and indicates the presence of "dramatized irony" (after Shepherd) in pericopes characterized by sandwich structure. In the second paragraph, the criteria of defining sandwich compositions and the basic (main) features which should be examined to determine if a pericope has 
a sandwich composition are discussed. Next, the author analyzes their occurrence in six texts which are commonly accepted by scholars as having sandwich composition (p. 59) and subsequent controversial pericopes, namely these for which there is no consensus as to whether they are indeed "sandwiches" (p. 60). According to Fr. Moj, there are nine "questionable" pericopes (pp. 53-54).

Unfortunately, I have not found the pericope Mk 6:34-52 among these texts, which is considered to be a possible sandwich composition by some commentators. ${ }^{3}$ The results of this insightful analysis on the presence of individual criteria in Markan pericopes have been presented graphically in two tables (pp. 59-60), which makes it very easy for the reader to learn whether the pericope has the required characteristics or not. The conducted study leads the author to the conclusion that two pericopes among the disputable ones [the second multiplication of the bread, asking for the sign - 8:1-10 (11-13) 14-21 and the presence of women and the laying of Jesus in the tomb - 15:40-41 (42-47 ) 16:1-8] bear narrative features of sandwich compositions. In this way, the author determines eight pericopes (six "classic" ones and two pericopes selected from the disputable ones), which will be subject to a detailed analysis in the next part of the work. In the final paragraph of the second chapter, the author includes a synoptic comparison of individual pericopes. His aim is to demonstrate that sandwich compositions are a characteristic feature of the narrative in the Gospel of Mark.

The second part of the work: "Exegesis of sandwich compositions", the most extensive one, consists of eight chapters, in which eight pericopes are subjected to a detailed exegetical analysis in the canonical order: 1) relatives of Jesus and the dispute about Beelzebub in 3:20-21 (22-30) 31-35;2) the daughter of Jairus and a woman suffering from hemorrhage in 5:21-24 (25-34) $35-43 ; 3)$ the mission of the twelve disciples and the death of John the Baptist in 6:6b-13 (14-29) 30-31;4) the second multiplication of the bread and asking for the sign in 8:1-10 (11-13) 14-21;5) Jesus and the fig tree and the expulsion of traders from the temple in 11:12-14 (15-19) 20-25;6) plot for the life of Jesus and the anointing in Bethany in $14: 1-2(3-9) 10-11 ; 7)$ the trial of Jesus and the denial of Peter in 14:53 (54) 55-65 (66-72); 8) the presence of women and the laying of Jesus in the tomb 15:40-41 (42-47) 16:1-8.

3 D. Kotecki, „I chciat ich ominać”, p. 125 quotes the opinion of C. Mazzucco, Il viaggio a Betsaida, p. 308 that "in Mk 6:52 it is important to link the miracle of multiplying bread and the walking of Jesus on the sea. The Evangelist, as Mazzucco correctly observes, referring the reader at the end of the second episode to the preceding miracle, gives an example of sandwich composition which used for specific theological purposes, suggests that these two events are closely related and one should be interpreted in the light of the other." See also D. Kotecki, Con Gesù nella barca, pp. 132-133. 
Each chapter is structured consistently according to the same pattern and includes: delimitation of the text according to time, place, people and subject; textual criticism; translation with a philological commentary, an indication of the specific semantic, morphological and syntactic specificity of the Greek text, which cannot be rendered in Polish translation; synoptic comparison which serves to identify specific features of each redaction, especially the grammatical and semantic specificity of the Markan relationship; the structure of the narrative; a detailed contextual analysis; the discussion of the meaning of the whole composition where the similarities of the terms and constructs used are presented, which constitute the interconnections of the two relations which form the sandwich composition. What deserves to be admired is an extraordinary methodological consistency in the analysis of individual pericopes. Conducted exegesis is factual, sometimes very meticulous and reliably respects the text and context.

It is particularly noteworthy that when the author discusses the delimitation of individual pericopes, he also refers to the contemporary editions of the Polish Bibles. He shows clearly that sometimes there is disagreement in defining the narrative framework of individual sandwich compositions and the proposed divisions of pericopes and the titles given to them do not take into account the existence of sandwich structure of a given pericope. The suggestions of the division of texts which can be found in the gospel lectionary used during the liturgy and in the newer biblical commentaries have undergone a similar analysis. The study of lectionaries and some commentaries leads to similar conclusions as in the case of editions of the Bible.

The third part of the monograph "The Role of Sandwich Compositions" is an eleventh chapter and consists of three paragraphs. In the first one, the author critically evaluates the importance of the criteria determining sandwich compositions. Based on the prior analyzes of individual pericopes Fr. Moj lists six criteria, which he rightly considers sufficient in determining sandwich compositions (p. 341). In the following paragraph he emphasizes the importance of sandwich compositions for particular stages of research: delimitation, textual criticism and synoptic comparison. In this paragraph, the author uses the results of a thorough analysis of pericopes from the second part of the book. The last paragraph is devoted to the question of the significance of sandwich technique for the theology of the Gospel of Mark. Analyzing the arrangement of sandwich compositions in the literary structure of the Gospel, Father Moj rightly concludes that the compositions appear in the section about the activities of Jesus in Galilee and the neighboring area (1:14-8:26) and bring together the main theological themes of this part of the Gospel: Jesus' power over the unclean spirits (3:20-35); Jesus' power over illness and death (5:21-43); mar- 
tyrdom of John the Baptist as the prediction of the fate of Jesus and His disciples (6:6b-31); the signs of Jesus as a manifestation of God's power (8:1-21). All these themes focus on the question about the identity of Jesus. The other four, in the section on events in Jerusalem (11:1-16:20), concern the essence of being a disciple: proper form of worship (11:12-25); bond with Jesus (14:1-11); regret and remorse for repudiating the relationship with Jesus (14:53-72); following the Risen Lord as a permanent formation of His disciples (15:40-16:8). The author also tries, quite convincingly, to explain why there are no sandwich compositions in the section about the way to Jerusalem (8:27-10:52). He observes there a linear development of the plot which has a specific purpose and the primary role of disciples (formation on the way). Relying on this, he rightly concludes that it was not possible to apply sandwich compositions in the middle section of the Gospel, the way to Jerusalem, as "the individual stages developed in the chronological order (approaching Jerusalem, the linear development of the plot), whereas the main characters were always disciples thus the criteria for constructing a sandwich composition, i.e. different characters in particular pericopes, was impossible to preserve" (p. 355).

The ending of the book summarizes in a very synthetic but clear and factual manner the results of the research. The numerous benefits of a reliable study of sandwich pericopes and the techniques of combining them have been rightly observed. This is important for biblical scholars, theologians, editors and translators of inspired texts, as well as liturgists who prepare the fragments of the Gospel for reading during the liturgy. The awareness of the presence of sandwich technique together with all interpretational consequences are also a sine qua non of the proper theological interpretation of pericopes in accordance with the idea of Mark the Evangelist.

The book ends with bibliography and abstract in English, giving international biblical scholars the opportunity to get familiar with the questions which are studied by Polish biblicists.

A monograph by Father Marcin Moj is an important academic contribution to the literary and theological studies on the Gospel according to St. Mark. In the light of reliable and correct analyzes of pericopes characterized by sandwich structures, the author not only confirms the literary artistry of St. Mark the Evangelist, but also shows the importance of this compositional technique for theology of the Gospel. Undoubtedly, this book enriches our understanding of the oldest and the shortest Gospel and is a very valuable and articulate confirmation of its literary and theological originality and kerygmatic character. 


\section{Bibliography}

Kotecki D., “' 'I chciał ich ominąć' (Mk 6,48)," Theologica Thoruniensia 1 (2000), pp. 111-131.

Kotecki D., Con Gesù nella barca (Mc 4,35-41; 6,45-52; 8,13-21). Contributo allo studio del discepolato nel Vangelo di Marco, Torun 2015.

Martini C.M., Stuchać Jezusa. Medytacje nad Ewangelia św. Mateusza, translated by F. Błaszkiewicz, S. Wąsik. Kraków 2000.

Mazzucco C., "Il viaggio a Betsaida dei discepoli di Gesù (Mc 6,45-8,22)," in: Voce di molte acque, Miscellanea di studi offerti a Eugenio Corsini, Torino 1994, pp. 305-321.

Rosik M., "Chrystologiczna funkcja interkalacji Markowych,” Quaestiones Selectae 18 (2004), pp. 111-137. 